\title{
ALX4 wt Allele
}

National Cancer Institute

\section{Source}

National Cancer Institute. ALX4 wt Allele. NCI Thesaurus. Code C74966.

Human ALX4 wild-type allele is located in the vicinity of 11 p11.2 and is approximately 50 $\mathrm{kb}$ in length. This allele, which encodes homeobox protein aristaless-like 4, plays a role in transcriptional regulation. Mutation of the gene is associated with parietal foramina 2. 